\title{
EFFECT OF AMBIENT TEMPERATURE ON DIESEL-ENGINE COMBUSTION CHARACTERISTICS OPERATING WITH ALCOHOL FUEL
}

\author{
M.K. Akasyah ${ }^{1, a}$, R. Mamat ${ }^{1, b}$, A. Abdullah ${ }^{2}$, A. Aziz ${ }^{1}$ and H.M. Yassin ${ }^{1}$ \\ ${ }^{1}$ Faculty of Mechanical Engineering, University Malaysia Pahang, \\ 26600 Pekan, Pahang, Malaysia

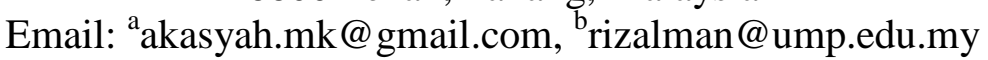 \\ ${ }^{2}$ Automotive Engineering Centre, Universiti Malaysia Pahang, \\ 26600 Pekan, Pahang, Malaysia
}

\begin{abstract}
Biofuel is an alternative fuel source for diesel engines. Nowadays, biofuel attracts more interest due to the depletion of mineral petroleum resources. The aim of this paper is to study the effect of ambient temperature on the combustion and performance of a diesel engine when using ethanol and methanol as fuels. The one-dimensional numerical analysis uses the GT-Power software program to simulate a commercial four-cylinder diesel engine. The diesel engine was simulated in order to study the characteristics of engine combustion when the engine is operating with ethanol and methanol as alternative fuels. The simulations were conducted under the full-load condition for an engine operating with diesel, ethanol, and methanol. Ambient temperatures used for each test were 30,40 , and $50{ }^{\circ} \mathrm{C}$. The results show that the in-cylinder pressure for ethanol is higher than that of methanol and diesel at different ambient temperatures, while methanol was found to yield a higher rate of heat release compared to ethanol and diesel. However, changes in ambient temperature in the inlet pipe do not affect the rate of heat release when using any fuel. It can be concluded that biofuels are excellent fuel alternatives to replace diesel in the future.
\end{abstract}

Keyword: Ambient temperature; diesel engine; ethanol, methanol; in-cylinder pressure.

\section{INTRODUCTION}

The internal combustion engine is a machine that converts the chemical energy in a fuel into mechanical work. In combustion engines, the chemical energy of the fuel is converted to thermal energy through combustion with the help of oxygen [1]. A strong release of thermal energy will result in the piston being pushed down and the crank rotated at a speed proportional to the kinetic energy received. Two types of internal combustion engine are very popular at present: gasoline and diesel engines [2-6]. Typically, a diesel engine is good for moving heavy machinery in rough conditions. Many studies have found that diesel engines are more efficient than gasoline engines in terms of thermal efficiency [1, 7-10]. Diesel engines are also more economical as well as more durable. However, today's increased use of petroleum fuels has resulted in the depletion of natural resources. Consequently, surveys into alternative fuel sources have been undertaken by many researchers. Biofuels, such as ethanol and methanol, are produced from biomass materials. Usually this fuel will be blended with petroleum fuels, namely with diesel and gasoline [11]. However, biofuels themselves can be used on their own. Biofuels can be described as cleaner burning fuels because they produce 
fewer air pollutants; the generation of pollutants allows diesel engines to achieve higher complete combustion [12]. Biofuel can serve as an alcohol-based fuel additive that provides oxygen which helps diesel engines to achieve more complete combustion. Indirectly, it will improve performance while reducing emissions such as particulate matter, hydrocarbon and carbon monoxide [13-17].

In modern engine research and studies, using hardware experiments alone would be very expensive and time-consuming, and many cause-and-effect relationships implicit in the test results are often hard to interpret. On the other hand, modelling and simulation approaches, although less precise in predicting the outcome of a specific test, could effectively isolate one variable at a time so enabling parametric studies to be conducted [18-20]. Therefore, simulation could identify cause-effect relationships more clearly, and a validated model could be a very useful tool in the study of new types of engines or engines running with new types of fuels. Since a clear understanding does not yet exist of the effect of using biofuel in a diesel engine, a simulation study of a biofuel engine is necessary, together with experimental study. Therefore, this study aims to measure the variations in diesel-engine performance as a function of the biofuel used. In this paper, one-dimensional simulation analyses in GT-Power were used to simulate four-cylinder diesel engines which are available in the Universiti Malaysia Pahang laboratory. This analysis involves combustion performance and engine performance. Operation of the engine is set at a speed of $2000 \mathrm{rpm}$ and full load in order to readily examine the experimental fuels used.

\section{SIMULATION SETUP}

GT-Power is based on one-dimensional modelling, representing the flow and heat transfer in pipes and other components of an engine system. In addition, many other specialized models can be applied for many kinds of system analysis [21-23]. It is known that power is work per unit of time. The torque of an engine is the ability to use the power generated. In the experiment, the torque was measured by a dynamometer. The crankshaft is connected to the engine dynamometer and brake power can be measured by the load applied to it. Figure 1 presents computational model of a fourcylinder, direct-injection, compression-ignition engine.

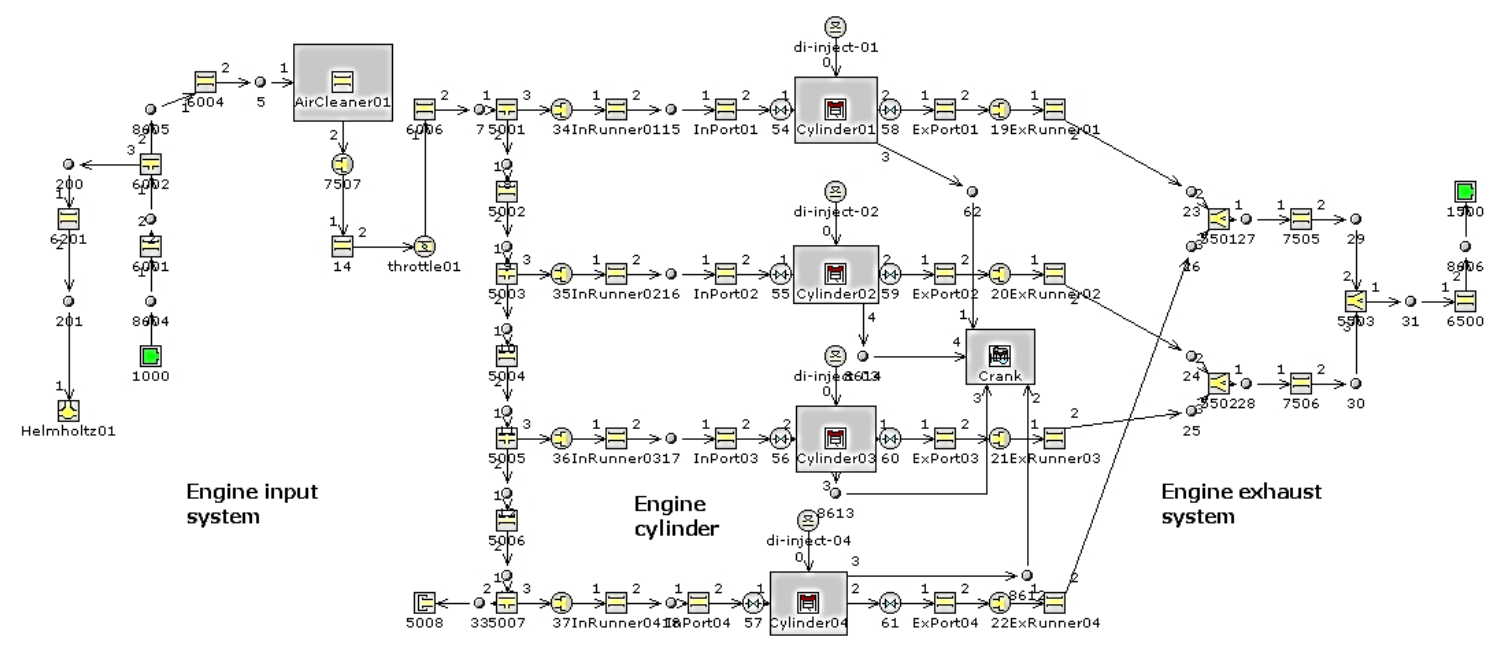

Figure 2. Computational model of a four-cylinder, direct-injection, compressionignition engine 
In this study, the development of a four-stroke, direct-injection (DI) diesel engine via simulation was undertaken. All the data were selected corresponding to the real engine with the specifications outlined in Table 1 . This engine is naturally aspirated, water-cooled, and equipped with a GNU vertical rot meter on the engine cooling system. The data were analyzed graphically using GT-Power (GT-Post) version 6.1 and Microsoft Excel. The fuel properties of diesel, ethanol and methanol are given in Table 2. The table shows that methanol has the highest oxygen content, while the heating value and cetane number are low compared to diesel. Ethanol and methanol also have lower boiling points compared to diesel.

Table 1. Specification of the Mitsubishi diesel engine.

\begin{tabular}{lc}
\hline Engine parameters & Value \\
\hline Model & Mitsubishi 4D68 \\
Type & Air-cooled diesel engine \\
Bore $(\mathrm{mm})$ & 82.7 \\
Stroke $(\mathrm{mm})$ & 93.0 \\
Displacement $(\mathrm{L})$ & 1.998 \\
Number of cylinders & 4 in-line \\
Compression ratio & 22.4 \\
Connecting rod length $(\mathrm{mm})$ & 150.0 \\
Piston pin offset $(\mathrm{mm})$ & 1.0 \\
Ignition system & Direct injection \\
\hline
\end{tabular}

Table 2: Properties of diesel and biofuel, [24, 25].

\begin{tabular}{lcccc}
\hline Fuel properties & Unit & Diesel & Ethanol & Methanol \\
\hline Density at $26.85^{\circ} \mathrm{C}$ & $\mathrm{kg} / \mathrm{m}^{3}$ & 822.8 & 789.0 & 792 \\
Cetane number & - & 55 & $<8$ & 5 \\
Kinematic viscosity at $40^{\circ} \mathrm{C}$ & $\mathrm{mm}^{2} / \mathrm{s}$ & 2.6 & 1.2 & 0.44 \\
Surface tension at $20^{\circ} \mathrm{C}$ & $\mathrm{N} / \mathrm{m}$ & 0.023 & 0.022 & 0.023 \\
Lower heating value & $\mathrm{MJ} / \mathrm{kg}$ & 42.7 & 27.7 & 21.1 \\
Specific heat capacity & $\mathrm{J} / \mathrm{kg}^{\circ} \mathrm{C}$ & 1850 & 2100 & 2545 \\
Boiling point & ${ }^{\circ} \mathrm{C}$ & $180-360$ & 78 & 65 \\
Oxygen & $\%$ weight & 0 & 34.8 & 49.9 \\
\hline
\end{tabular}

\section{RESULTS AND DISCUSSION}

The analysis focuses on the combustion process in order to identify the effects the biofuel has on the in-cylinder pressure and rate of heat release by outlining the influence in the most representative operating modes. Moreover, measured levels of different parameters (ambient temperature and fuel type) were analyzed in order to gain a better understanding of the observed trends. Simulations using GT-Power were undertaken to study the effect of inlet air temperature on performance of the diesel engine. In Figure 2, a $\mathrm{P}-\mathrm{V}$ diagram comparison between methanol, ethanol, and diesel at $30^{\circ} \mathrm{C}$ air inlet temperature is illustrated. The results show that methanol has a higher differential pressure compared with that of diesel and ethanol. These differences indicate that methanol has enough thermal energy to provide tremendous pressure in the engine cylinder [26]. This is because, during the top isentropic processes, greater methanol 
energy is transferred out of the system in the form of work than for diesel and ethanol. These conditions represent the different combustion behaviors of fuels during the combustion period [14]. Therefore, it can be concluded that different fuel properties in the test fuels result in the most different combustion behaviors.

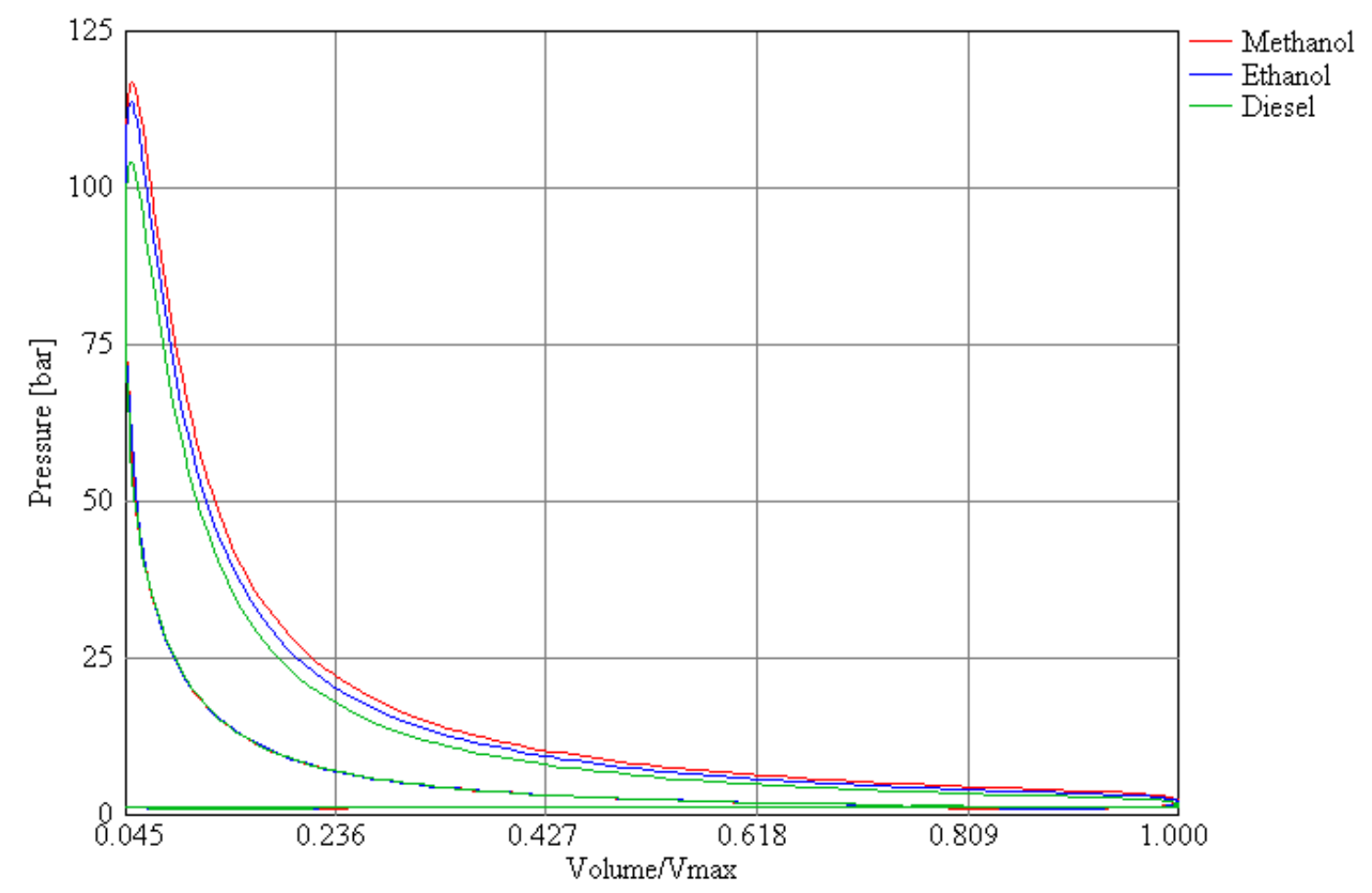

Figure 3. Pressure--volume (P-V) diagram of diesel, methanol and ethanol engines operating at $30^{\circ} \mathrm{C}$ ambient temperature.

Figure 3 shows the difference in pressure involving diesel, ethanol, and methanol at an ambient temperature of $30^{\circ} \mathrm{C}$. Through visual inspection, we find that methanol has the highest peak-pressure point at 120.1 bar. This is followed by ethanol (113.5 bar) and diesel (103.9 bar). This is due to methanol having the highest specific heat value. However, ethanol produces increased pressure the fastest among all the tested fuels after the start of injection at $-17^{\circ}$. Significant changes occur in the crank angle between $-15^{\circ}$ and $-10^{\circ}$. At this point in the cycle, the engine is already approaching its maximum compression stroke and the fuel is ready to be injected with fuel/air at the $0^{\circ}$ crank angle.

Figure 4 shows a comparison of the maximum peak-pressure points of each fuel at ambient temperatures of $30^{\circ} \mathrm{C}, 40^{\circ} \mathrm{C}$ and $50^{\circ} \mathrm{C}$. In these graphs, 4 (a), 4 (b) and 4 (c), the higher ambient temperature input and the lower points of peak pressure in the cylinder are displayed. Diesel yielded the highest drop rate of $1.35 \%$, followed by methanol $(1.24 \%)$ and ethanol $(0.58 \%)$. The additional oxygen content in high-methanol causes a more complete combustion and causes higher pressure than in the other fuels $[26,27]$. This shows that the higher the ambient temperature in the inlet pipe, the better the work rate. Although the pressure drop is small, it is demonstrated that increasing the ambient temperature will result in reduced engine performance. 


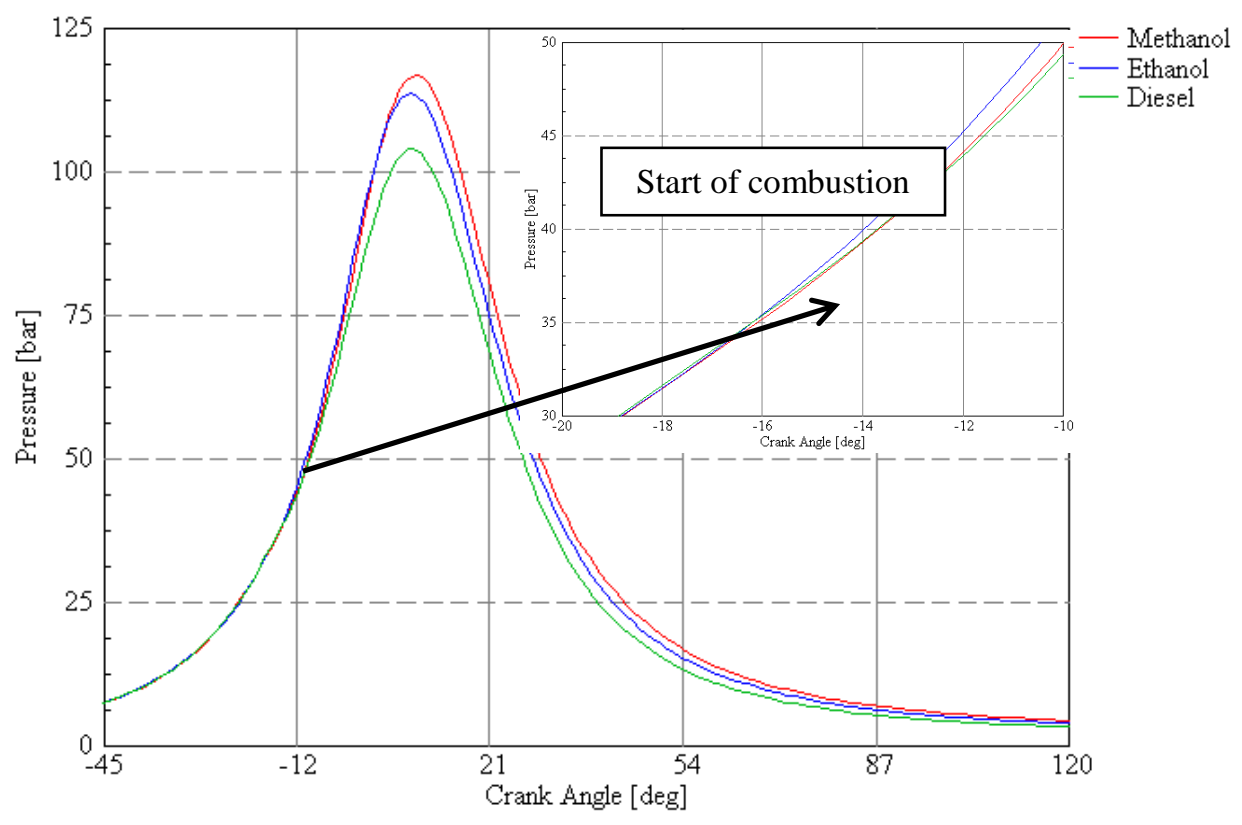

Figure 4. In-cylinder pressure of diesel, methanol and ethanol engines operating at $30^{\circ} \mathrm{C}$ ambient temperature.

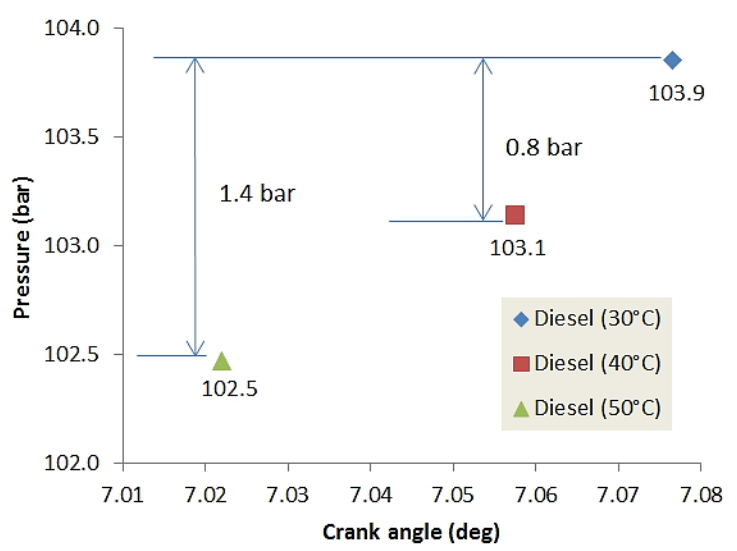

(a)

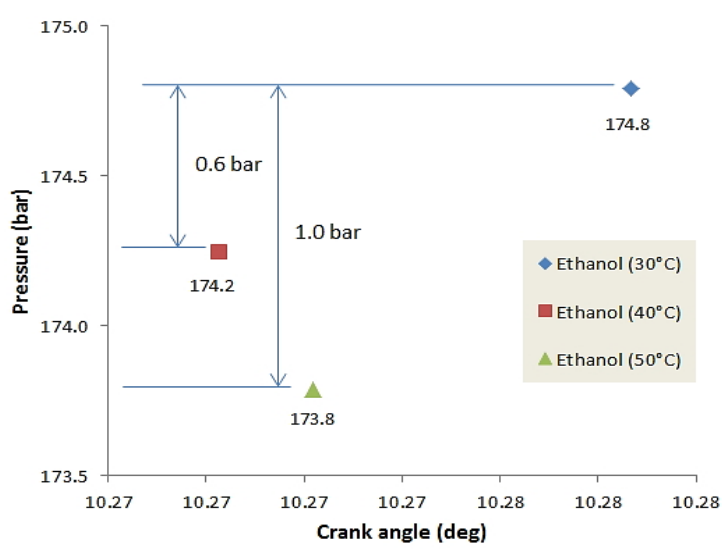

(b)

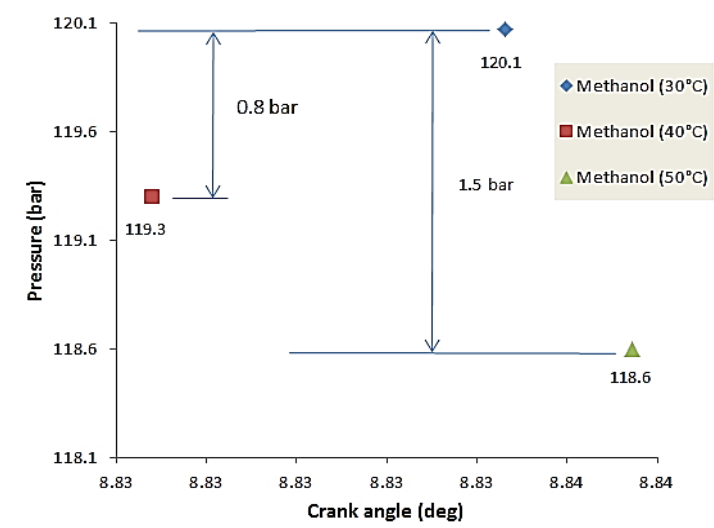

(c)

Figure 5. Comparing the peak dispersion of (a) diesel, (b) ethanol and (c) methanol incylinder pressure at ambient temperatures of $30^{\circ} \mathrm{C}, 40^{\circ} \mathrm{C}$ and $50^{\circ} \mathrm{C}$, respectively. 
In Figure 5, a comparison between the peak difference of in-cylinder pressure for diesel, ethanol, and methanol for ambient temperatures of $30^{\circ} \mathrm{C}, 40^{\circ} \mathrm{C}$ and $50^{\circ} \mathrm{C}$ are shown. Based on these observations, in-cylinder pressure produces the lowest peak point at the highest ambient temperature. Thus, combustion of methanol at an ambient temperature of $30^{\circ} \mathrm{C}$ produces the highest pressure of 120.1 bar. The lowest point is the peak pressure combustion of diesel at a temperature of $50^{\circ} \mathrm{C}$. Ethanol also has a consistent peak point of combustion pressure between those of diesel and ethanol. The combustion of ethanol at an ambient temperature of $30^{\circ} \mathrm{C}$ will produce the most outstanding in-cylinder pressure in the engine. In contrast, the burning of diesel at an ambient temperature of $50^{\circ} \mathrm{C}$ will produce the weakest in-cylinder pressure in the engine.

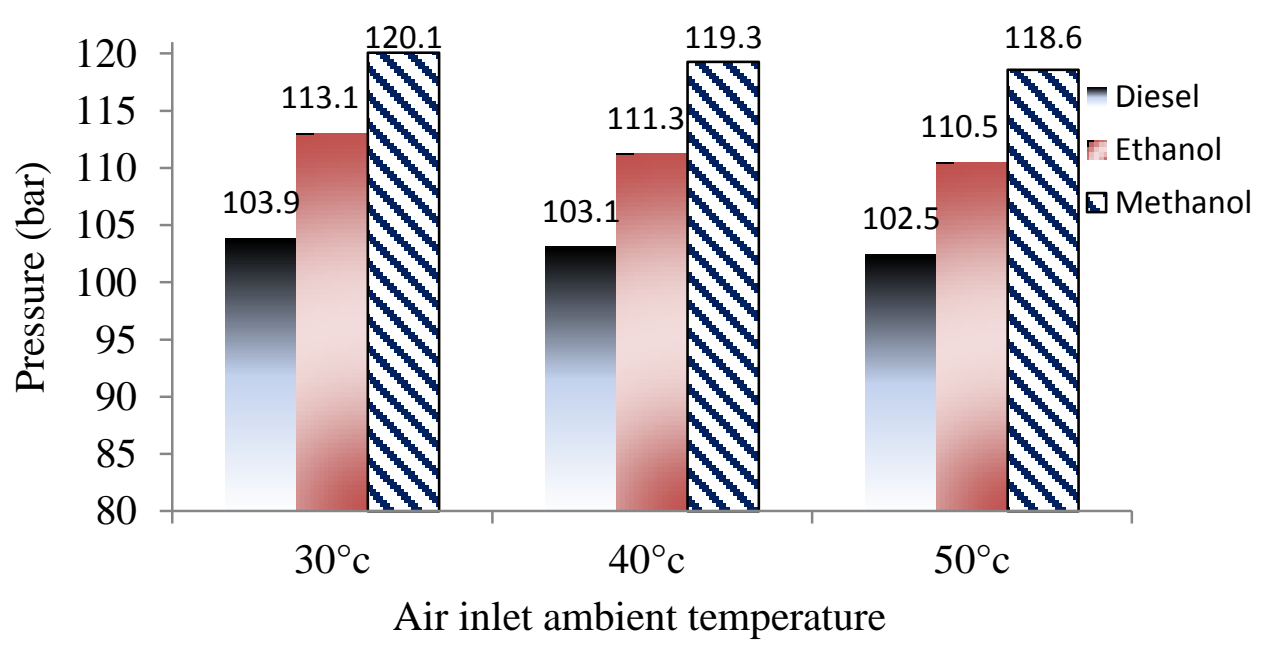

Figure 6. Comparing the peak dispersion of diesel, ethanol and methanol in-cylinder pressure between ambient temperatures of $30^{\circ} \mathrm{C}, 40^{\circ} \mathrm{C}$ and $50^{\circ} \mathrm{C}$.

Figure 6 shows the heat-release rate of diesel, ethanol, and methanol at a $30^{\circ} \mathrm{C}$ ambient temperature. Graphically, the heat-release rate for diesel is very high at a crank angle of $11.8^{\circ}$. Ethanol can yield higher pressure in the combustion chamber, as previously mentioned, but has a peak heat-release rate that is lower than diesel by $26.9 \%$. Methanol yielded a peak heat-release rate of $30.9 \%$, lower than those of diesel and ethanol. As shown, methanol has two peaks that are of almost the same magnitude at crank angles of $6.7^{\circ}$ and $9.5^{\circ}$ after top dead center (ATDC). This was due to heat release earlier than in other fuels from $17.6^{\circ}$ before top dead center (BTDC). Despite having a low-pressure discharge rate, diesel has a better combustion rate. However, the high heat-release rate will result in the formation of NOx much more readily due to the high temperature in the cylinder [1, 28, 29]. Although diesel has a high peak heatrelease rate value, it does not mean the total heat release of diesel is also high. Figure 7 shows that the heat-release rate of methanol is higher and faster than the other two fuels. At the crank angle of $0^{\circ}$, the heat-release rate of methanol reaches almost $22 \%$ compared to diesel which is less than $10 \%$. However, although diesel is comparatively slow and hot at crank angles near zero because of the slow rate of heat release, it becomes considerable at a $13^{\circ}$ crank angle and is equal to methanol at a $27^{\circ}$ crank angle. The diesel showed fast ignition due to the high cetane number [12]. A rapid heatrelease rate is indicative of the increased effectiveness of the combustion process in 
internal combustion engines [30]. In this case, it may be concluded that heat-release analysis, though based on a simplified approach if compared with more enhanced engine-analysis techniques, is a useful way of explaining experimental or simulation results as it helps to clarify the trends in the main engine parameters

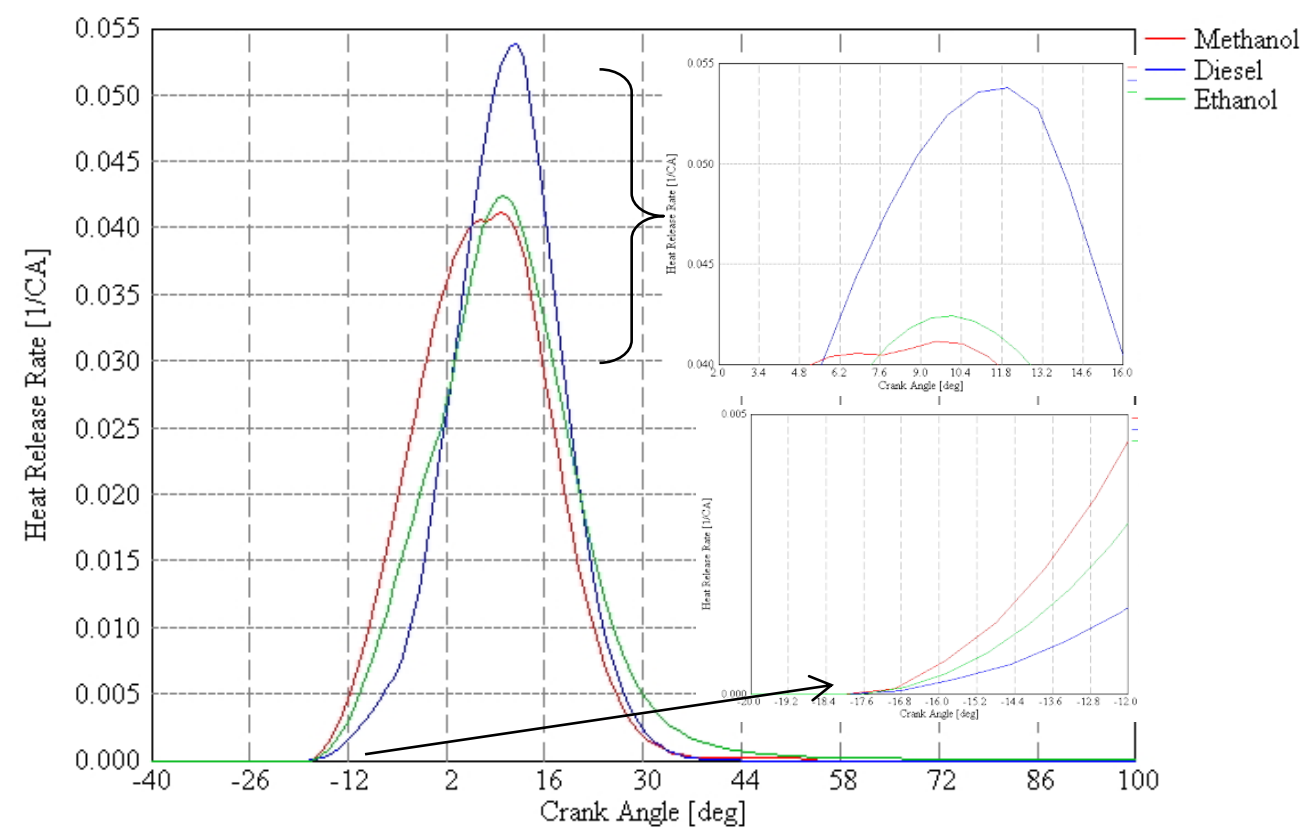

Figure 7. Rate of heat released of diesel, methanol and ethanol in engines operating at $30^{\circ} \mathrm{C}$ ambient temperature.

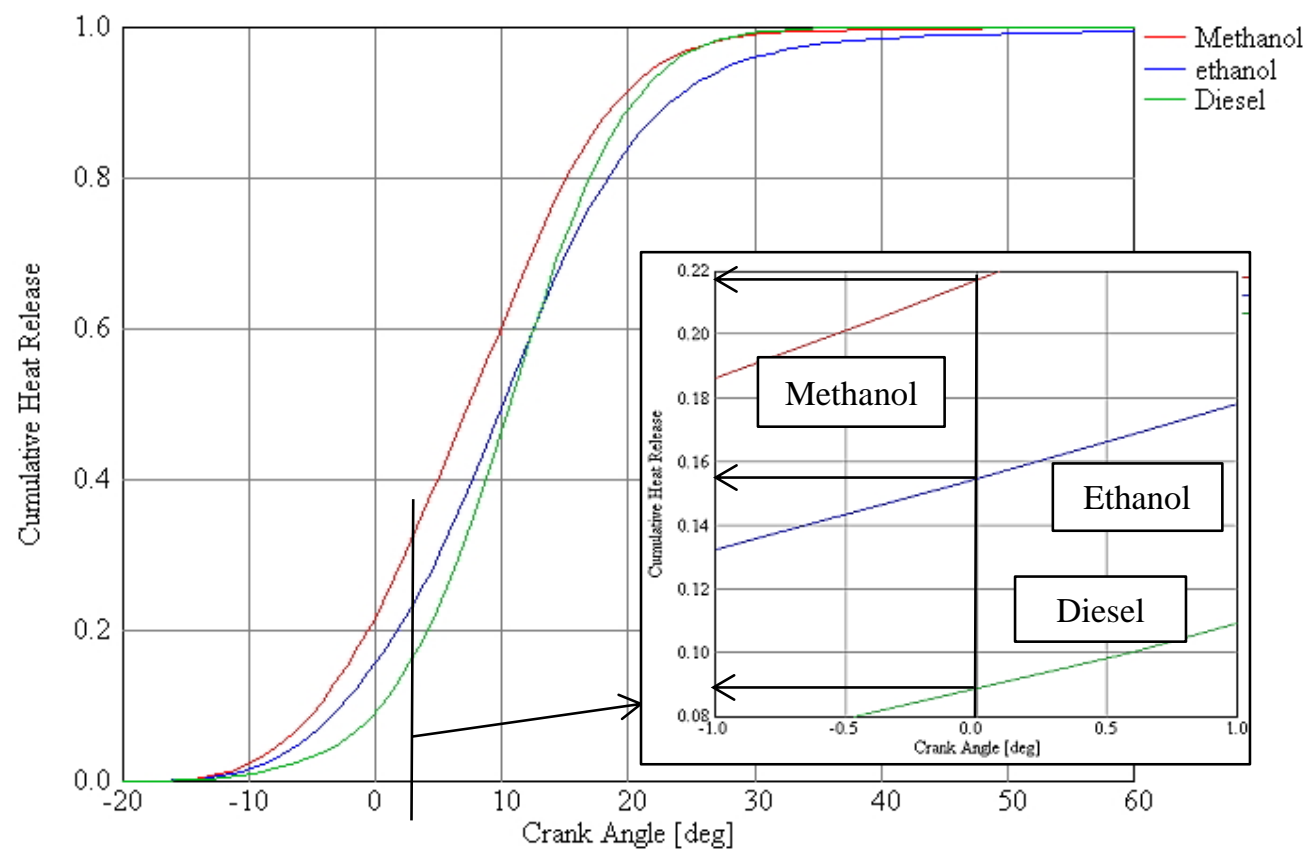

Figure 8. Cumulative rates of the heat release of diesel, methanol and ethanol in engines operating at $30^{\circ} \mathrm{C}$ ambient temperature. 


\section{CONCLUSIONS}

Generally, alcohol fuel has a significant effect on the combustion characteristics of diesel engines. The main results of this investigation show that:

1. Ethanol produces the highest pressure of 174.8 bar at an ambient temperature of $30^{\circ} \mathrm{C}$. Diesel produced the lowest peak-pressure combustion at a temperature of $50^{\circ} \mathrm{C}$.

2. The pressure in the cylinder decreased with the increase in inlet air temperature in all simulation results used in the present work. The decrease in in-cylinder pressure will produce weak engine performance.

3. The heat-release rate for diesel is the highest at a crank angle of $11.8^{\circ}$ in comparison to the other fuels. Methanol has two peaks at almost the same value, at crank angles $6.7^{\circ}$ and $9.5^{\circ}$ ATDC.

4. Methanol is the best fuel in terms of the heat-release rate in the combustion chamber.

\section{ACKNOWLEDGMENTS}

The authors would like to thank Universiti Malaysia Pahang for providing facilities during the course of this study

\section{REFERENCES}

[1] Heywood J. Internal combustion engine fundamentals. New York: McGrawHill; 1988.

[2] Hindren A. Saber RRIA-B, Ziyad J. Talabany. Effect of ambient air temperature on specific. Journal of Science and Engineering. 2013; 1:1-7.

[3] Rahim R, Mamat R, Taib MY, Abdullah AA. Influence of fuel temperature on a diesel engine performance operating with biodiesel blended. Journal of Mechanical Engineering and Sciences. 2012;2:226-36.

[4] Ghobadian B, Najafi G, Nayebi M. A semi-empirical model to predict diesel engine combustion parameters. Journal of Mechanical Engineering and Sciences. 2013;4:373-82.

[5] Yusop AF, Mamat R, Mat Yasin MH, Ali OM. Effects of particulate matter emissions of diesel engine using diesel-methanol blends. Journal of Mechanical Engineering and Sciences. 2014;6:959-67.

[6] Aziz Hairuddin A, Wandel AP, Yusaf T. Effect of different heat transfer models on a diesel homogeneous charge compression ignition engine. International Journal of Automotive and Mechanical Engineering. 2013;8:1292-304.

[7] Kumar AS, Maheswar D, Reddy KVK. Comparison of diesel engine performance and emissions from neat and transesterified cotton seed oil. Jordan Journal of Mechanical and Industrial Engineering. 2009;3:190 - 7.

[8] Abdullah NR, Shahruddin NS, Mamat R, Ihsan Mamat AM, Zulkifli A. Effects of air intake pressure on the engine performance, fuel economy and exhaust emissions of a small gasoline engine. Journal of Mechanical Engineering and Sciences. 2014;6:949-58. 
[9] Kamil M, Rahman MM, Bakar RA. Integrated simulation model for composition and properties of gases in hydrogen fueled engine. International Journal of Automotive and Mechanical Engineering. 2013;8:1242-155.

[10] Shamsudeen A, Abdullah S, Ariffin AK, Rasani MRM, Ali Y. Design and simulation of a cylinder head structure for a compressed natural gas direct injection engine. International Journal of Automotive and Mechanical Engineering. 2014;9:1620-9.

[11] Komninos NP, Rakopoulos CD. Modeling HCCI combustion of biofuels: A review. Renewable and Sustainable Energy Reviews. 2012;16:1588-610.

[12] Park SH, Youn IM, Lee CS. Influence of ethanol blends on the combustion performance and exhaust emission characteristics of a four-cylinder diesel engine at various engine loads and injection timings. Fuel. 2011;90:748-55.

[13] Labeckas G, Slavinskas S, Mažeika M. The effect of ethanol-diesel-biodiesel blends on combustion, performance and emissions of a direct injection diesel engine. Energy Conversion and Management. 2014;79:698-720.

[14] Mat Yasin MH, Yusaf T, Mamat R, Fitri Yusop A. Characterization of a diesel engine operating with a small proportion of methanol as a fuel additive in biodiesel blend. Applied Energy. 2014;114:865-73.

[15] Yusop AF, Yasin MHM, Mamat R, Abdullah AA, Aziz A. PM Emission of Diesel Engines using Ester-ethanol-diesel Blended Fuel. Procedia Engineering. 2013;53:530-5.

[16] Azad AK, Ameer Uddin SM, Alam MM. A comprehensive study of DI diesel engine performance with vegetable oil: an alternative boi-fuel source of energy. International Journal of Automotive and Mechanical Engineering. 2012;5:57686.

[17] Yusaf T, Hamawand I, Baker P, Najafi G. The effect of methanol-diesel blended ratio on CI engine performance. International Journal of Automotive and Mechanical Engineering. 2013;8:1385-95.

[18] Liu H-P, Strank S, Werst M, Hebner R, Osara J. Combustion Emissions Modeling And Testing Of Neat Biodiesel Fuels. ASME 2010 4th International Conference on Energy Sustainability: ASME 2010.

[19] Maghbouli A, Yang W, An H, Li J, Chou SK, Chua KJ. An advanced combustion model coupled with detailed chemical reaction mechanism for D.I diesel engine simulation. Applied Energy. 2013;111:758-70.

[20] Kumar S, Kumar Chauhan M, Varun. Numerical modeling of compression ignition engine: A review. Renewable and Sustainable Energy Reviews. 2013;19:517-30.

[21] GTI. GT-ISE User's manual - Vers. 6.1. . 601 Oakmont lane, Suite 220, Westmont, IL, USA: Gamma Technologies Inc.; 2004.

[22] Kamil M, Rahman MM, Bakar RA. An integrated model for predicting engine friction losses in internal combustion engines. International Journal of Automotive and Mechanical Engineering. 2014;9:1695-708.

[23] Kamil M, Rahman MM, Bakar RA. Performance evaluation of external mixture formation strategy in hydrogen fueled engine. Journal of Mechanical Engineering and Sciences. 2011;1:87-98.

[24] Rakopoulos CD, Antonopoulos KA, Rakopoulos DC. Experimental heat release analysis and emissions of a HSDI diesel engine fueled with ethanol-diesel fuel blends. Energy. 2007;32:1791-808. 
[25] Moon S, Tsujimura T, Oguma M, Chen Z, Huang Z, Saitou T. Mixture condition, combustion and sooting characteristics of ethanol-diesel blends in diffusion flames under various injection and ambient conditions. Fuel. 2013;113:128-39.

[26] Masimalai SK. Influence of methanol induction on performance, emission and combustion behavior of a methanol - diesel dual fuel engine. SAE Technical paper No. 2014-01-1315; 2014.

[27] Qi DH, Chen H, Geng LM, Bian YZ, Ren XC. Performance and combustion characteristics of biodiesel-diesel-methanol blend fuelled engine. Applied Energy. 2010;87:1679-86.

[28] Lavoie, G.A., Heywood, J.B., Keck JC. Experimental and theoretical investigation of nitric oxide formation in internal combustion engines. Combustion Science and Technology 1970;1:313.

[29] Musculus MPB, Miles PC, Pickett LM. Conceptual models for partially premixed low-temperature diesel combustion. Progress in Energy and Combustion Science. 2013;39:246-83.

[30] Shahir SA, Masjuki HH, Kalam MA, Imran A, Fattah IMR, Sanjid A. Feasibility of diesel-biodiesel-ethanol/bioethanol blend as existing CI engine fuel: An assessment of properties, material compatibility, safety and combustion. Renewable and Sustainable Energy Reviews. 2014;32:379-95. 